foregår der, er mest en kulisse i fortellingene. Vi hører litt om grenseløse krav og høyt tempo, men for personene vi følger, består løsningene $\mathrm{i}$ at de forandrer seg individuelt, med litt hjelp fra støttespillere og litt kognitiv terapi. Iblant er det sikkert så enkelt. Men det presenteres nærmest som et sesam sesam mot sykmeldinger for angst og depresjon. Dette vil kanskje være hjelp til selvhjelp for mange som i likhet med persongalleriet her har høyt kvalifiserte jobber, sjefer som gjerne vil beholde dem, og ikke minst et nokså veldefinert og avgrenset problem. Men de fleste sykmeldte arbeidstakere har dårligere utgangspunkt enn dette. De fleste av oss er nøkternt sett billigere å bytte ut enn å ta hensyn til. Og vi har gjerne mer enn ett problem. Da kan det gjøre vondt verre hvis NAV-medarbeidere og arbeidsgivere har lest seg til for stor tro på enkle, og ikke minst raske, individrettede løsninger. Gode løsninger krever kanskje mest av alt god tid.

\section{Ebba Wergeland}

Arbeidstilsynet

Oslo

\section{Godt og elegant om helse}

\author{
John Gunnar Mæland \\ Hva er helse \\ 160 s. Oslo: Universitetsforlaget, 2009 \\ Pris NOK 159 \\ ISBN 978-82-15-01253-7
}

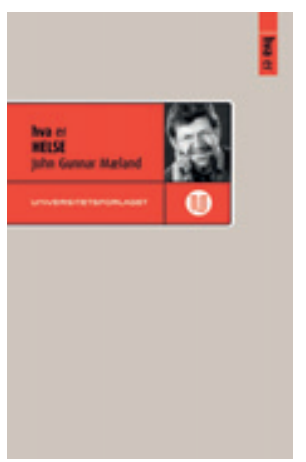

Lar du seg fascinere av lekre, små bøker om store, komplekse temaer, som tillit, angst, kosmos, krig, feminisme, medisin eller EU? Da er Universitetsforlagets «Hva er»-serie noe for deg. Den omfatter allerede mer enn 30 modige titler. Professor i sosialmedisin John Gunnar Mæland har påtatt seg å drøfte spørsmålet hva er helse? Oppgaven kan se uskyldig ut, men fra et teoretisk perspektiv er temaet både komplekst og kontroversielt. Forfatteren starter og avrunder da også sin utredning med henvisning til historien om de blinde menn og elefanten: Beskrivelsen av en elefant vil avhenge av hvilken del av den man tar utgangspunkt i. Det samme kan sies om fenomenet helse.

Hva er helse handler om hva begrepet helse rommer, hvilke dimensjoner det omfatter, og hvordan det kan beskrives og måles. Forfatteren har satt seg godt inn i tematikken, skriver lett og presist, og det er inspirerende å følge fremstillingen. Vi presenteres for det biomedisinske helsebegrepet (helse som fravær av sykdom), samt for mer holistiske ideer, ideer om helse som velbefinnende, og helse som evne til å realisere sine mål, mer eller mindre uavhengig av sykdom. De ulike modellene betraktes på en meningsfylt måte i lys av tider og trender i samfunnsutviklingen; ikke minst er drøftelsen av WHOs helsedefinisjon klok. Vi stifter bekjentskap med flere navn fra idéhistorien på en måte som fremmer gjenkjennelse og oversikt. I det store og hele er boken ganske lavmælt i sin fremstilling, men av og til trår forfatteren til med klare meninger. Han slår bl.a. til mot det han opplever som en industri av livskvalitetsforskning, der mye har vært «drevet av tall og ikke av innhold». En god formulering - som nok kan sies å ha relevans for flere forskningsarenaer.

Denne boken kan bidra til allmenndannelsen hos alle som jobber i (eller utdanner seg til) vårt såkalte helsevesen. Den har også verdi for lesere som på ulike måter kommer i kontakt med helsebegrepet; politikere, journalister, lærere, samfunnsvitere, alternative behandlere og folk flest.

Dette dreier seg om hvordan man kan begrepsfeste og forstå helse. Forfatteren sier rimeligvis lite om hva som gir god helse, og det var heller ikke meningen. Men det er fint hvis Universitetsforlaget en dag velger å gå videre og utgi boken Hva er kildene til helse. Tiden er inne for en klok drøftelse av dette. Ideen er herved lansert.

\section{Linn Getz}

Allmennmedisinsk forskningsenhet Institutt for samfunnsmedisin

Norges teknisk-naturvitenskapelige universitet

\section{Sædprøveanalysen fra A til ^}

Verdens helseorganisasjon

WHO laboratory manual for the examination and processing of human semen

5. utg. 287 s, tab, ill. Genève: WHO, 2010. Pris CHF 50

ISBN 978-92-4-154778-9

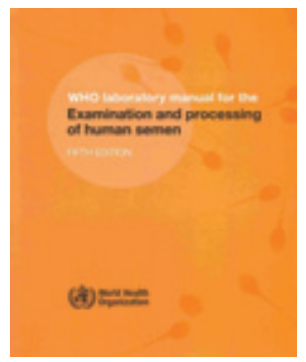

Sædprøveanalyser utføres rutinemessig blant annet ved utredning av infertile par, ved sæddonasjon og etter vasektomi, i tillegg til i diverse forskningssammenhenger. For å sikre at resultatene blir så korrekte som mulig, og at prøvesvar fra ulike laboratorier skal kunne sammenliknes, er standardisering av analyseprosedyrer og kvalitetssikring av laboratoriene av fundamental betydning.

Ekspertene bak den femte utgaven av

WHOs manual for å undersøke human sæd har som mål å beskrive hvordan man kan oppnå dette. Den inneholder derfor detaljert informasjon og anbefalinger om de fleste aspektene ved sædprøveanalysen. Manualen er delt inn i tre hoveddeler, i tillegg til referanser og en appendiksdel. I den første hoveddelen tar man for seg standardmetoder og ulike tester for analyse av sædprøver. De to andre hoveddelene omhandler henholdsvis preparasjon av sædprøver og kvalitetssikring av laboratorier som utfører sædprøveanalyser.

Manualen er oversiktlig, lettlest og inneholder mange fine illustrasjoner og lett forståelige tabeller. Totalt sett gjør dette at den egner seg godt både som oppslagsbok og som lærebok, det vil si at den gjerne kan leses fra perm til perm.

I manualen presenterer man en rekke nyheter. For eksempel har man kommet frem til nye referanseverdier for sædprøveanalyser hvor disse er basert på statistiske beregninger av sædprøveanalyser fra menn som oppnådde at deres partner ble gravid innen 12 måneder. Dette har blant annet medført at nedre referansegrenser for spermiekonsentrasjon og normal spermiemorfologi er endret til henholdsvis 15 millioner/ $\mathrm{ml} \operatorname{og} 4,0 \%$. Det er også verd å merke seg at det totale antall spermier per ejakulat ser ut til å være av større prediktiv verdi med henblikk på sjanse for graviditet, enn spermiekonsentrasjon. Dessuten foreslår man en forbedret og samtidig forenklet klassifisering av spermiemotilitet hvor denne deles inn i tre grupper: (i) progressivt motile, (ii) ikke-progressivt motile og (iii) immotile spermier. Interessant er det også å lese anbefalingen om at sædvolum kan måles ut fra sædprøvens vekt, noe som forutsetter at man veier prøveglasset før sædprøven tas.

Det eneste jeg savner etter å ha lest manualen, er en DVD som vedlegg til boken, der man demonstrerer viktige aspekter ved sædprøveanalysen. Som alternativ kunne WHO opprettet en Internettside med diverse videoklipp.

Manualen er først og fremst beregnet på helsepersonell som jobber med fertilitet. For å kunne tilegne seg så mye kunnskap som mulig, bør spesielt leger og laboratoriepersonell lese den i sin helhet. Dessuten bør laboratoriesjefer iverksette nødvendige tiltak for å tilpasse sædprøveanalysen etter de anbefalingene som man gir i manualen. Det er først etter å ha etablert slike tiltak at både helsepersonell og pasienter fullt ut vil kunne dra nytte av manualen.

Redaksjonsteamet bak den femte utgaven av WHOs manual for undersøkelse og bearbeiding av human sæd har utført en formidabel jobb. De gratuleres herved!

Manualen kan lastes ned gratis fra følgende Internett-adresse: www.who.int/ reproductivehealth/publications/infertility/ 9789241547789/en/

\section{Erling Ekerhovd}

Medicus

Trondheim 